\title{
Does the Change of Company Name Matter for the Investors? Evidence from Indonesia
}

\section{Bambang Sutrisno ${ }^{1}$ and Azimah Hanifah ${ }^{2}$}

\author{
${ }^{1}$ Universitas Muhammadiyah Jakarta, Indonesia, e-mail: bsutrisno.umj@gmail.com \\ ${ }^{2}$ Universitas Muhammadiyah Jakarta, Indonesia, e-mail: azimahhanifah240401@gmail.com
}

\begin{abstract}
Changing the name of the company requires careful consideration and is not an easy thing. Companies need to assess the impact and benefits of changing company names. This study aims to examine the impact of company name changes on stock returns on the Indonesia Stock Exchange. This research uses the event study methodology. With a sample of 32 companies listed on the Indonesia Stock Exchange that changed their names in 2013-2017, the results show that there are significant abnormal returns on days $-4,-2,+1,+3$, and +5 , but the abnormal returns are negative. The results also prove that there is no difference in abnormal stock returns in the days before and after the announcement of changes in company names. The findings suggest that the market does not react to information about changes in company names.
\end{abstract}

Keywords: change of company name; abnormal return; Indonesia stock exchange

\section{Introduction}

The company name is the identity of an organization and is a pride for business owners, shareholders, managers, and employees. It is also widely accepted that the company name is the essential thing in the company's relationship with its customers. A name will set attitudes and tones and is the first step towards forming a corporate personality.

When a company decides to change its name, it is generally expected that the company will not change the name corporation unless it is beneficial to the company's stakeholders. It may also be that changes in company names serve as a good signal to convey information about management strategies for the company's future direction (Karpoff and Rankie, 1994).

In addition to stock prices, changes in company names also affect investors in making decisions. In buying shares of a company, the investors require various considerations in the form of information related to the company itself. With this information, investors are not harmed when selling or buying shares of the company. In the case of changing the name of the company, investors can react positively or negatively depending on the reason. A different reason for the corporate name change will cause a different investor reaction (Kot, 2011). If the reason is for restructuring, investors tend to have a positive reaction so that they can add value to the company's stock price, but on the contrary, if the reason is for the reputation, the investor will be more likely to react negatively.

Several studies on the effect of changes in the company name on stock prices have been carried out in the capital market. The results of prior research related to the corporate name change on stock price in some countries with different market characteristics are inconclusive. The objective of this study is to examine the impact of the company's name change on stock prices in a developing country, namely Indonesia.

Today the company is increasingly aware of the importance of company names related to the company's reputation. Consequently, company managers are more active in managing company names as a brand. This thing can be seen with the emergence of new brands that are consciously designed to relate to the corporate value embraced, such as taking the theme of life, competency, unity, vision, and performance. Apparently, by focusing more on values that are common to companies; generally, it can be a cause of failure in creating differentiation whereas the differentiation will differentiate one company from another. 
Responding to business competition that tends to be tight, not a few companies start changing names. The point is in addition to differentiating from competitors as well so that investors have a better perception. Investors will assess the company before investing some funds in a company, one of which is taken into consideration is the stock price. Change of company name is one of the factors that affect stock prices, can have a positive or negative effect.

Empirical studies tend to find the market reaction to changes in company names. Bosch and Hirschey (1989) found that the market reacted positively, Karpoff and Rankine (1994) showed a positive reaction to stock prices but the effect was small, Lee (2001) expressed a positive reaction to investors so that stock prices increased. Agnihotri and Bhattacharya (2016) concluded that investors responded positively to changes in company names. On the other hand, Howe (1982) and Josev et al. (2004) found no strong evidence for the market reaction to changes in company names, even though there were positive price changes. Kot (2011) concluded that name changes influenced stock prices in the short term but did not affect the long term. Gupta and Aggarwal (2014) showed that there were no significant abnormal returns around the announcement day of company name changes on the National Stock Exchange and Bombay Stock Exchange.

Based on the description above, there are two hypotheses proposed in this study, namely:

$\mathrm{H}_{1}$ : There is abnormal return in the days around the announcement of the change of company name on the Indonesia Stock Exchange.

$\mathrm{H}_{2}$ : There is a difference in abnormal stock returns in the days before and after the announcement of changes in company names.

\section{Research Methodology}

The population in this study is all companies listed on the Indonesia Stock Exchange that changed the company name from 2013 to 2017. This study uses purposive sampling with the following criteria. First, the company's shares are actively traded during the study period. This criterion is important because inactive stocks are less feasible to observe where the company's stock prices tend not to change. Second, the company's shares do not carry out other corporate actions in one month before and after the name change. This thing is essential to determine to avoid bias result. Third, the company must have a positive beta.

This study employs an event study methodology. The main variable studied in this study is the abnormal return. It is calculated as the difference from the actual return to the expected return. The abnormal return is formulated as follows:

$$
A R_{i t}=R_{i t}-E\left(R_{i t}\right)
$$

where $A R_{i t}$ is the abnormal return of stock $i$ for period $t, R_{i t}$ is the actual return of stock $i$ for period $t$, and $E\left(R_{i t}\right)$ is the expected return of stock $i$ for period $t$.

Actual return is calculated by the following formula:

$$
R_{i t}=\ln \frac{P_{t}}{P_{t-1}}
$$

where $R_{i t}$ is the actual return of stock $i$ in period $t, P_{t}$ is the stock price $i$ at period $t$, and $P_{t-1}$ is the stock price $i$ in period $t-1$.

The calculation of expected return uses the single index model with the following formula:

$$
E\left(R_{i t}\right)=\alpha_{i}+\beta_{i} E\left(R_{m t}\right)
$$

where $\alpha_{i}$ is part of stock returns $i$ which is not affected by market performance, $\beta_{i}$ is the sensitivity of stock returns $i$ to market movements (also referred to as stock beta $i$ ), and $R_{m t}$ is market return in period $t$ which is calculated by the following formula:

where JCI is the Jakarta Composite Index.

$$
R_{m t}=\ln \frac{J C I_{t}}{J C I_{t-1}}
$$


Several steps need to be done in testing the research hypothesis. First, testing the normal or not distribution of research data using the Shapiro-Wilk test. Second, if the tested data is normally distributed, then the hypothesis testing uses the one sample t-test and t-paired samples test. Third, if the research data is not normally distributed, then hypothesis testing uses Wilcoxon One Sample test and Wilcoxon paired samples test.

\section{Results and Discussion}

The population in this study is the companies listed on the Indonesia Stock Exchange that changed their names in 2013-2017. Forty-four public companies changed their names for the research period. There are several reasons why companies changed their names. Many public companies changed their names because of the changes in the business sector. Changing the business sector is not an easy thing. Many companies are forced to change the business sector solely as a strategy to survive.

The determination of the research sample is determined by the criteria that the public companies listed continuously in 2013-2017 on the Indonesia Stock Exchange. This study uses a single index model to calculate beta. The beta calculation is done for each company with a time interval of t-95 to t-6. If the company has a negative beta, it will be excluded from the research sample. The final sample of this study is thirty-two companies. Table 1 shows the process to determine the final sample.

This study calculates abnormal returns before and after changes in company names. Table 2 shows that the average abnormal return before and after the announcement of changes in the company name is $-1.83 \%$ and $-1.97 \%$ respectively. The abnormal returns after the company's name changes are lower than before the company's name changes. Median abnormal return both in the days before and after the announcement of the company's name change is negative. The negative values of mean and median imply that the announcement of company name changes is negatively interpreted by the investors.

Before testing the research hypothesis, this study needs to test the normality of data by employing the Shapiro-Wilk test. Table 3 shows that all data are abnormal. Therefore, the research hypotheses testing uses Wilcoxon one sample test and paired samples.

Table 1 Determination of Research Sample

\begin{tabular}{lc}
\hline \multicolumn{1}{c}{ Information } & Number of companies \\
\hline Number of companies that change names & 44 \\
\hline Companies that were not actively traded during the study period & 4 \\
\hline Companies actively traded during the study period & 40 \\
\hline Companies that conduct other corporate actions & 3 \\
\hline Companies that do not conduct other corporate actions & 37 \\
\hline Companies with a negative beta & 5 \\
\hline Companies with a positive beta & 32 \\
\hline Final sample & 32 \\
\hline
\end{tabular}


Table 2 Descriptive Statistics of the Abnormal Returns

\begin{tabular}{ccccccc}
\hline \multirow{2}{*}{ Day } & $\begin{array}{c}\text { Abnormal } \\
\text { Return }\end{array}$ & Mean & Median & $\begin{array}{c}\text { Standard } \\
\text { Deviation }\end{array}$ & Minimum & Maximum \\
\hline \multirow{2}{*}{5} & Before & -0.0412 & -0.0043 & 0.1935 & -0.8400 & 0.2100 \\
& After & -0.0213 & -0.0074 & 0.0489 & -0.1600 & 0.1400 \\
\hline \multirow{2}{*}{4} & Before & -0.0415 & -0.0056 & 0.1171 & -0.3300 & 0.1100 \\
& After & -0.0191 & -0.0184 & 0.0871 & -0.0160 & 0.1300 \\
\hline \multirow{2}{*}{3} & Before & 0.0304 & -0.0091 & 0.1173 & -0.1100 & 0.3800 \\
& After & -0.0112 & -0.0075 & 0.1215 & -0.2500 & 0.3300 \\
\hline \multirow{2}{*}{2} & Before & -0.0361 & -0.0189 & 0.0890 & -0.2700 & 0.1500 \\
& After & -0.0135 & -0.0086 & 0.1245 & -0.2800 & 0.3100 \\
\hline \multirow{2}{*}{1} & Before & -0.0029 & -0.0108 & 0.1338 & -0.3000 & 0.2900 \\
& After & -0.0335 & -0.0113 & 0.1386 & -0.5100 & 0.1700 \\
\hline \multirow{2}{*}{ Overall } & Before & -0.0183 & -0.0038 & 0.0471 & -0.1600 & 0.0300 \\
& After & -0.0197 & -0.0167 & 0.0324 & -0.1100 & 0.0500 \\
\hline
\end{tabular}

Table 3 Normality Test

\begin{tabular}{ccccc}
\hline \multirow{2}{*}{ Day } & \multicolumn{2}{c}{ Probability } & \multicolumn{2}{c}{ Conclusion } \\
\cline { 2 - 5 } & Before & After & Before & After \\
\hline 5 & 0.000 & 0.004 & abnormal & abnormal \\
\hline 4 & 0.002 & 0.000 & abnormal & abnormal \\
\hline 3 & 0.000 & 0.006 & abnormal & abnormal \\
\hline 2 & 0.000 & 0.003 & abnormal & abnormal \\
\hline 1 & 0.000 & 0.000 & abnormal & abnormal \\
\hline Overall & 0.000 & 0.001 & abnormal & abnormal \\
\hline
\end{tabular}

Table 4 shows that there are several days where the abnormal returns are different from zero. This result indicates that abnormal returns exist in those days, namely days $-4,-2,+1,+3$, and +5 . Meanwhile, there is no abnormal return on other days. All median abnormal returns are negative. The median of abnormal return for five days before the change of name changes is statistically equal to zero. On the other hand, the median of abnormal return after the company name change is statistically different from zero.

Furthermore, this study examines whether there is a difference in abnormal returns before and after the announcement of changes in company names. This research employs the Wilcoxon paired samples test. In Table 5, it is known that the Z-score is -0.6700 (p-value $=0.3243$ ). Because the $p$-value is higher than the level of significance $(\alpha=5 \%)$, then hypothesis two is accepted. In other words, there is no difference in abnormal returns before and after the announcement of changes in company names. This study finds no evidence of a positive influence on abnormal stock returns when the company announced to change its name on the Indonesia Stock Exchange. Even abnormal returns after the announcement of changes in the company name are lower than before the announcement of changes in company names, where the median abnormal return before the name change is $-0.38 \%$, while the median abnormal return after the name change is $-1.67 \%$. 
The results of this research differ from some previous studies. Bosch and Hirschey (1989) find a positive influence on changes in company names on the New York Stock Exchange. Cooper et al. (2001) find that companies that change their names get the positive and significant abnormal returns on the New York Stock Exchange, American Stock Exchange, and Nasdaq Stock Exchange. Kot (2011) concludes that changes in company names have a short-term effect on stock prices in Hong Kong Stock Exchange.

If the prior studies in other capital markets reported significant abnormal returns in the announcement of changes in company names with a tendency to positive abnormal returns, then the question that must be answered is why the phenomenon is not found in Indonesia, even otherwise the abnormal returns tend to be negative. There is a reason that investors in Indonesia do not think too much about the name of a company in the decision to buy and sell shares. The decision to sell and buy shares is more influenced by other things. The abnormal returns that tend to be negative indicate that the investors penalize companies that change their names, or the investors do not care about name changes. This interpretation is supported by the lack of fluctuating stock prices in the days around the announcement of changes in company names.

This study does not find strong evidence that the change in the company name has a positive effect on stock returns on the Indonesia Stock Exchange. This study has some weaknesses. First, the use of the Single Index Model produces small beta, so it is not a good proxy for systematic risk. The use of other risk estimation models might result in better abnormal return value. Second, the Indonesia Stock Exchange is an emerging market, where the investors tend to be less concerned about the information entering the market so that the stock prices formed in the capital market are more influenced by other factors, such as fluctuations in economic indicators. Third, this study does not explicitly distinguish the reasons for changes in company names. The results of the study may be different if the name changes are classified according to the underlying reasons or the reason for the name change is used as one of the variables in this study.

Table 4 Result of Wilcoxon One-Sample Test

\begin{tabular}{cccc}
\hline Day & Median AR & Wilcoxon Statistic & P-Value \\
\hline-5 & -0.0043 & 83.0 & 0.166 \\
\hline-4 & -0.0056 & 60.0 & 0.022 \\
\hline-3 & -0.0091 & 112.0 & 0.939 \\
\hline-2 & -0.0189 & 30.0 & 0.001 \\
\hline-1 & -0.0108 & 99.0 & 0.242 \\
\hline+1 & -0.0113 & 70.0 & 0.018 \\
\hline+2 & -0.0086 & 80.0 & 0.153 \\
\hline+3 & -0.0075 & 96.0 & 0.005 \\
\hline+4 & -0.0184 & 59.0 & 0.182 \\
\hline+5 & -0.0074 & 64.0 & 0.018 \\
\hline Before & -0.0038 & 92.0 & 0.166 \\
\hline After & -0.0167 & 45.0 & 0.011 \\
\hline
\end{tabular}


Table 5 Result of Wilcoxon Paired Samples Test

\begin{tabular}{lllll}
\hline \multicolumn{1}{c}{ Data } & Median & Difference & Z-Score & P-Value \\
\hline AR Before & -0.0038 & -0.0129 & -0.6700 & 0.3243 \\
AR After & -0.0167 & & & \\
\hline
\end{tabular}

\section{Conclusion}

The purpose of this study is to analyze the impact of the company's name change on stock returns on the Indonesia Stock Exchange for the period of 2013-2017 with a sample of 32 companies. This study concludes that there are several days with significant abnormal returns, namely days $-4,-2,+1,+3$, and +5 , but the values of the abnormal returns are negative. This finding indicates that the market does not react to the announcement of changes in company names. This study also finds that there is no difference in abnormal stock returns in the days before and after the announcement of changes in company names. Thus, the corporate name change does not affect stock returns on the Indonesia Stock Exchange.

The results of this research have some implications for the company, investor, and future research. For companies, it is expected to consider more mature if they want to decide to change the name of the company because the investors are less responsive when there is information about changes in company names. The investors do not have to consider their investment decisions based on the announcement of the change of the company name. Some suggestions for future research are as follows. First, future research is needed to use the capital asset pricing model or Fama-French three-factor model (Sutrisno and Nasri, 2018) to estimate the expected return. Second, future research should focus on the study of specific reasons for the company name change, for example by specifying name changes due to mergers or changes in the business sector.

\section{References}

Agnihotri, A. \& Bhattacharya, S., 2016. Corporate name change and the market valuation of firms: Evidence from an emerging market. International Journal of the Economics and Business, 24(1), pp. 73-90.

Bosch, J. \& Hirschey, M., 1989. The valuation effects of corporate name changes. Financial Management, 18(4), pp. 65-73.

Cooper, M. J., Dimitrov, O. \& Rau, P. R., 2001. A rose.com by any other name. Journal of Finance, 56(6), pp. 2371-2388.

Gupta, M. \& Aggarwal, M., 2014. The impact of stock name changes on shareholder wealth. Journal of Management Research, 14(1), pp. 15-24.

Howe, J., 1982. A rose by any other name? A note on corporate name changes. Financial Review, 17(4), pp. 271-278.

Josev, T., Chan, H. \& Faff, R., 2004. What's in a name? Evidence on corporate name changes from the Australian capital market. Pacific Accounting Review, 16(1), pp. 57-75.

Karpoff, J. M. \& Rankine, G., 1994. In search of a signaling effect: The wealth effects of corporate name changes. Journal of Banking and Finance, 18(6), pp. 1027-1045.

Kot, H. W., 2011. Corporate name changes: Price reactions and long-run performance. PacificBasin Finance Journal, 19(2), pp. 230-244.

Lee, P. M., 2001. What's in a name?: The effects of '.com' name changes on stock prices and trading activity. Strategic Management Journal, 22(8), pp. 793-804.

Sutrisno, B. \& Nasri, R., 2018. Is more always better? An empirical investigation of the CAPM and the Fama-French three-factor model in Indonesia. Semarang, KNE Social Sciences, pp. 454-468. 